Session XXXX

\title{
Design Exercises and Projects in Energy Engineering Course
}

\author{
Kendrick Aung \\ Department of Mechanical Engineering \\ Lamar University, Beaumont, Texas 77710
}

\begin{abstract}
Energy Engineering is a senior elective course for mechanical engineering majors in the Department of Mechanical Engineering at Lamar University. In order to increase the design content in elective courses, team-based design projects and assignments were extensively used in Energy Engineering. The course covers four parts: energy resources, energy conversion systems, energy conservation, and environmental pollution. During the course, exercises and team projects were assigned to design renewable and traditional energy conversion systems. This paper describes the assignments and projects used in the course to enhance the design experience of the students. Detailed descriptions of each design project and the student design solution were given.
\end{abstract}

Introduction

Energy affects the lives of everyone in so many ways, economically, technically, and environmentally. Thus, integration of energy and its many aspects such as energy conservation technologies and environmental impacts of energy generation, in the educational curriculum of science, technology, and engineering students is essential. In order to address this need, an elective course, Energy Engineering, was developed and implemented in the Mechanical Engineering Department at Lamar University. The course was designed in order to demonstrate how knowledge from junior level thermal/fluid science classes could be used to design and develop energy systems. The course topics and contents were based on similar courses at other universities $^{1-3}$. However, more emphasis was placed on the design procedure and calculations related to different energy systems in order to increase the design contents of the course as required by Accreditation Board for Engineering and Technology (ABET). Students were also encouraged to use web-based resources and computational tools to carry out analysis and design calculations. This paper describes the assignments and projects used in the course to enhance the design experience of the students.

Course Description 
Energy Engineering is a multi-disciplinary subject that encompasses thermodynamics, fluid mechanics, engineering economics, energy conversion, energy conservation, energy audit and management, and environment ${ }^{4}$. The course is developed as an elective course for the senior undergraduate students but first-year graduate students are also allowed to take the course. At Lamar University, the prerequisites for the course are the completion of undergraduate fluid mechanics, thermodynamics, and heat transfer courses. The class is a 3-credit hour class with 3 hours of lecture time each week.

The course consists of four parts: energy resources, energy conversion, energy conservation, and environmental impacts of energy generation. Both non-renewable and renewable energy resources were covered. Non-renewable energy resources include petroleum, coal, natural gas, and nuclear while renewable energy resources are solar, biomass, wind, geothermal energy, and hydro. The energy conversion devices covered in the course include internal combustion engines, steam and gas turbines, photovoltaic cells, wind turbines, geothermal heat pumps, fuel cells, and microturbines. In discussing these energy conversion systems, capital and operating costs were given so that the students would have some ideas on the economic aspects of these energy systems and how cost might influence their choice of system. Different types of energy conservation technologies were discussed in the third part of the course. Some of the energy conservation topics covered were cogeneration or Combined Heat and Power (CHP), trigeneration, waste heat recovery, and pinch technology. The main focus on environmental impact section is on the sources of each pollutant and the technologies for remediation, reduction, and elimination of these pollutants. The pollutants discussed include $\mathrm{NO}_{\mathrm{x}}, \mathrm{SO}_{\mathrm{x}}, \mathrm{CO}, \mathrm{CO}_{2}$, particulate matters (PM), Volatile Organic Compounds (VOC), and CFCs. Effects of these pollutants on the environment in the form of smog, acid rain, global warming, and ozone hole are also presented.

When designing design exercises and projects for the students in this course, it should be noted that the theoretical materials for the design of alternative and conventional energy systems were already covered in detail. For example, the design of a wind turbine was covered in lecture discussing topics such as energy available in the wind, the effects of wind availability and wind speed, power coefficient, efficiency of energy conversion from the wind to electricity. So the students already have the technical knowledge and engineering equations to carry out the assignments and projects. In addition, the design guides and tutorials for many energy systems were either provided on the course web site or as class handouts. Some of the design guides used for this course were listed here:

$$
\begin{aligned}
& \text { A Guide to PV System Design and Installation } \\
& \text { Guided Tour on Wind Energy } \\
& \text { Cogeneration Guide }
\end{aligned}
$$

Extensive case studies for different energy systems were used to demonstrate the actual implementations and related issues to the students.

The main goal in choosing the design exercises were to encourage students to apply their technical knowledge in a customer oriented setting where they were required to specify the system that satisfied the customer specifications. Thus, the final solutions of the exercises and 
projects involved the selections of a production energy system (a real wind turbine from a wind turbine manufacturer) from real-world vendors so that the students would be able to tackle an design-type problems encountered in industrial setting rather than solving a standard textbook style problems. In addition, simple cost analysis and impact on environment in terms of pollutant emissions were required for many design exercises and all projects.

The intention of the instructor was to encourage students to look beyond the textbook problems and to relate the technical knowledge and principles from the textbooks to the actual implementation of these principles in manufacturing different types of energy systems. In addition, these exercises and projects required the students to conduct literature search and develop understanding of actual energy systems and their specifications. To the best of the author's knowledge, these types of exercises and projects could not be found in any of the texts available on energy and energy systems. However, it was the author's strong belief that these exercises and projects provided exposure of real-world problems and systems to the students that might prove to be very beneficial to the students in looking beyond the box (text) and understanding the big picture.

\section{Design Exercises}

The instructor assigned several design-type exercises to the students during the course and three of them were discussed here. In solving design exercises, many web-based resources were used such as technical specifications of energy systems, costs and design parameters, design sheets, etc. Students also used computational tools provided by the instructor or webbased tools such as TEST, an expert system for thermodynamics ${ }^{8}$.

A design exercise for solar energy involves sizing the solar water heating system for a home in Florida. The students are asked to determine the area and number of collectors needed for a typical household. The problem statement was given below:

"Imagine that the instructor has retired and moved to Tampa, Florida. The instructor wants to install a solar domestic hot water system for his home. He asks his former student to help him choose the solar collector. The number of people in his household is 5 and the house has 4 bedrooms. The water storage tank will use 2.5-in fiberglass for insulation and the system will not have a heat exchanger. The tilt angle of the solar collector will be $35^{\circ}$ facing east. Use the collector rating for medium temperature and the solar collector specifications, choose the appropriate model of the solar collector, and specify the number of collectors needed. Use the worksheet attached to solve the problem. Estimate the capital cost and the payback period of the chosen system."

For this exercise, the students were asked to use the design sheet ${ }^{9}$ from Florida Solar Energy Center. The design sheet provided a step-by-step guide to determine the size of the water storage tank and compute the total area of the solar collector needed for the given hot water requirement. Using the area of the solar collector, the students could choose the specific collector from a list available ${ }^{10}$ on the web site of the Florida Solar Energy Center or from the class handouts. Once the number and size of the solar collector were determined, the cost and the 
associated savings in electricity could be determined by the table available on the same web site $^{11}$ or estimated from the class handouts. The design sheet also required the user to do the final design check that clearly showed the students that the final design should always be checked against the assumption made in developing the design procedure, an important step in design most often neglected in many design exercises.

Another design-type exercise used was to compute the performance of a GE MS9001FA gas turbine using a software program and compare with the data given by GE. The performance data of the MS9001FA can be obtained from GE web site ${ }^{12}$. The students use CyclePad program $^{13}$ or TEST to solve this exercise. CyclePad program was introduced to the students in their thermodynamic class and it is used as the main computational tool for analysis and design of thermodynamic systems such as gas turbine and combined cycle. Close agreements were found and students felt confident using the program to carry out the design in the latter part of the course. A variation on this exercise can be to specify steam turbine or combined cycle power plants instead of the gas turbine power plant.

Another design exercise is to compute the available power for a range of pressure head and flow rate to build a micro hydro power plant. The students use MicroHydroPower Calculator from Energy Alternative Limited ${ }^{14}$ to solve this exercise. The calculator can determine the potential microhydro resource at either an existing or a new system. The calculator was used in the online microhydropower course offered by the same company. The same company also offered design spreadsheets and calculators on photovoltaic (PV), solar heating, and wind as well as carbon emissions.

Design Projects

The use of group projects in engineering provides cooperative learning environment for students to gain teamwork skills. Thus, two group projects were assigned in this course. The first project involves designing a power plant to generate electricity for a city. The city may be small, medium or large. Each student group is assigned different energy generation systems such as a coal-fired steam power plant, fuel cell, and natural gas-fired combined cycle. Each group designs its power plant and provides estimates on the capital and operating costs of the plant. In addition, the students need to estimate the environmental impact of their power plant in terms of pollutant emission. Since this is an open-ended design project, the students need to research and make their own assumptions in order to tackle the problem. Each project involved the following steps that were required in every design project:

(1) Develop the problem statement in terms of technical specifications

(2) Research operating and technical parameters associated with each design

(3) Make assumptions and constraints to produce engineering specifications of the problem

(4) Carry out design calculations and the specifications of final design

(5) Identify and choose the actual energy system that meets the engineering specifications of Step 3

(6) Conduct economic analysis and estimate the payback period

(7) Estimate the environmental impacts based on pollutant emissions 
One project is to specify a gas turbine power plant for a town of 50,000 people and estimate the cost of the power plant. Through research students found out the data needed for the project such as electricity consumption per person, capital cost of a typical gas turbine plant, cost of fuel, and cost of electricity. Based on theses data, the students used CyclePad to design the gas turbine power plant and determine power output, efficiency, and heat rate. Using the results, they recommended Siemens EconoPac V64.3A as the suitable power plant for the town. They also determined the capital cost and the annual fuel cost to determine the payback period for the plant. Moreover, the students compared $\mathrm{NO}_{\mathrm{x}}$ emission from the gas turbine power plant with a coal-fired power plant of the same capacity to understand the impact of using clean natural gas.

Another project is to design a 350MW wind farm. In this project, the students were given the power required so they only needed to choose the type and number of wind turbines to produce $350 \mathrm{MW}$ of electricity. Students made the assumptions on the parameters such as height and wind conditions of the location, spacing between turbines, power coefficient, and efficiencies of the transmission and generation. Based on these data, the students chose $2 \mathrm{MW}$ Bonus turbine with a design wind speed of $12 \mathrm{~m} / \mathrm{s}$. The total number of turbines required is 260 with a capital cost of about $\$ 500$ million. In comparison with a coal fired power plant, the wind farm would result in reduction of 30,000 tonnes of SO emissions, 10,000 tonnes of $\mathrm{NO}_{\mathrm{x}}$ emission, and 2.6 million tones of $\mathrm{CO}_{2}$.

Another project is to design a $3000 \mathrm{MW}$ hydro power plant. This is a large-scale power plant and the students are to perform a design analysis to determine the efficiency and flow rate required. Then, water- turbine generator system needs to be identified. As in previous projects, the capital cost of the power plant and the reduction in pollutant emissions are to be calculated. Students made the assumptions on the parameters such as available water head, length of the pipes, and the efficiencies. Using these data, they determined that 6 Francis turbines with 500 MW capacity each. Here, the students estimated the power plant cost without considering the cost of the dam and related costs. In addition, the students failed to consider the amount of water storage needed to provide the flow rate required for the turbine-generators.

Other projects were variations of the projects described above: design of a combined cycle power plant for a town of 500,000 people, design of a $350 \mathrm{~kW}$ wind turbine, design of a 30 $\mathrm{kW}$ microhydro power plant and design of a coal-fired power plant for a town of 150,000 people.

\section{Conclusions}

Energy Engineering is a senior elective course for mechanical engineering majors in the Department of Mechanical Engineering at Lamar University. In order to increase the design contents in elective courses, team-based design projects and assignments were extensively used in Energy Engineering. During the course, exercises and team projects were assigned to design renewable and traditional energy conversion systems. This paper describes the assignments and projects used in the course to enhance the design experience of the students. Detailed descriptions of each design project and the student design solution were given. 
Bibliography

1. Hutzel, W. J., "Energy Conservation in Thermal Power Courses," Proceedings of the 2002 ASEE Annual Conference and Exposition, Montreal, Canada, 2002.

2. Schumack, M., "Incorporation of an Energy Conservation Theme into Thermal Science Courses," Proceedings of the 2002 ASEE Annual Conference and Exposition, Montreal, Canada, 2002.

3. Hodge, B. K., "Alternate Energy Systems - A New Elective," Proceedings of the 2002 ASEE Annual Conference and Exposition, Montreal, Canada, 2002.

4. Aung, K., "Energy Engineering: Development of a New Senior Elective Course," Proceedings of the 2004 ASEE Annual Conference and Exposition, Salt Lake City, Utah, 2004.

5. "A Guide to PV System Design and Installation," California Energy Commission Report, 2001.

6. "Guided Tour on Wind Energy," Danish Wind Turbine Manufacturers Association, www.windpower.org, 2001.

7. "European Education Tool on Cogeneration", EduCogen Project Report, 2001.

8. TEST The Expert System for Thermodynamics, http://kahuna.sdsu.edu/testcenter/, 2004.

9. $\quad$ http://www.fsec.ucf.edu/solar/apps/sdhw/gp10sizing.pdf, Florida Solar Energy Center, 1992.

10. http://www.fsec.ucf.edu/solar/testcert/collectr/tprdhw.htm

11. $\quad$ http://www.fsec.ucf.edu/solar/apps/sdhw/dhwsave.htm.

12. http://www.gepower.com/prod_serv/products/gas turbines cc/en/f class/ms $9001 \mathrm{fa} . \mathrm{htm}$

13. CyclePad, Qualitative Reasoning Group, http://www.qrg.ils.nwu.edu/projects/NSF/Cyclepad/aboutcp.htm.

14. http://www.energyalternatives.ca/Downloads/MicroHydroCalc.exe

Biography

KENDRICK AUNG is an assistant professor in the Department of Mechanical Engineering at Lamar University. He received his Ph.D. degree in Aerospace Engineering from University of Michigan in 1996. He is an active member of ASEE, ASME, AIAA and Combustion Institute. He has published over 50 technical papers and presented several papers at national and international conferences. 